ORIGINAL RESEARCH ARTICLE

\title{
Larch (Larix dahurica Turcz) Growth Response to Climate Change in the Siberian Permafrost Zone
}

Viacheslav I. Kharuk ${ }^{1,2^{*}}$, Kenneth J. Ranson ${ }^{3}$, Il'ya A. Petrov ${ }^{1}$, Maria L. Dvinskaya ${ }^{1}$, Sergei T. $\operatorname{Im}^{1,2,4}$, Alexei S. Golyukov $^{1,2}$

${ }^{1}$ Sukachev Institute of Forest, Federal Scientific Center, Russian Academy of Science, Siberian Branch, Academgorodok 50/28, Krasnoyarsk, 660036 Russia

${ }^{2}$ Siberian Federal University, Svobodny str.79, Krasnoyarsk, 660041 Russia ${ }^{3}$ NASA's Goddard Space Flight Center, Code 618, Greenbelt, MD 20771, USA.

${ }^{4}$ Reshetnev Siberian State University of Science and Technology, Krasnoyarsky rabochy str. 31, Krasnoyarsk, 660014 Russia

${ }^{*}$ Corresponding author: email: kharuk@ksc.krasn.ru, tel: 8-391-243-88-25

Kenneth J. Ranson

kenneth.j.ranson@nasa.gov

Ilya A. Petrov

petrovilsoran@gmail.com

Maria L. Dvinskaya

mary_dvi@ksc.krasn.ru

Sergei T. Im

stim@ksc.krasn.ru

Alexei S. Golyukov

jedirevan@yandex.ru

\section{Abstract}

Larch-dominant communities are the most extensive high latitude forests in Eurasia and are experiencing the strongest impacts from warming temperatures. We analyzed larch (Larix dahurica Turcz) growth index (GI) response to climate change. The studied larch-dominant communities are located within the permafrost zone of Northern Siberia at the northern tree limit (ca. N67³8', E99 $07^{\prime}$ ). Methods included dendrochronology, analysis of climate variables, root zone moisture content, and satellite-derived gross (GPP) and net (NPP) primary productivity. It was found that larch response to warming included a period of increased annual growth increment (GI) (from the 1970s to ca. 1995) with a follow on GI decline. Increase in GI correlated with summer air temperature, whereas an observed decrease in GI was caused by water stress (vapor pressure deficit and drought increase). Water stress impact on larch growth in permafrost was not observed before the onset of warming (ca. 1970). Water limitation was also indicated by GI dependence on soil moisture stored during the previous year. Water stress was especially pronounced for stands growing on rocky soils with low water holding capacity. GPP of larch communities showed an increasing trend, whereas NPP stagnated. A similar pattern of GI response to climate warming has also been observed for Larix sibirica Ledeb, Pinus sibirica Du Tour and Abies sibirica Ledeb in the forests of southern Siberia. Thus, warming in northern Siberia permafrost zone resulted in an initial increase in larch growth from the 1970s to the mid-1990s. After that time, larch growth increment has decreased. Since ca. 1990 water stress at the 
43 beginning of the vegetative period became, along with air temperature, a main factor affecting larch growth within 44 the permafrost zone.

46 Keywords Larix dahurica - Tree radial growth - Larch forests · Northern treeline - Tree response to warming · Larch and permafrost $\cdot$ Growth index $\cdot$ Climate impact on trees

\section{Bullets}

50 Initial larch growth increase followed by depression since the mid-1990s

51 Growth decrease caused by increased water stress

52 Water stress became one of the main factors affecting larch growth

53 GPP of larch communities are increasing, whereas NPP stagnated 
Larch stands, composed of Larix dahurica Turcz, L. sibirica Ledeb, and L. cajanderi Mayr cover about $70 \%$ of the permafrost area in Russia (with roughly one third covered by Larix dahurica). The northern tree line in Siberia is formed sequentially (from west to east) by Larix sibirica, L. dahurica, and L. cajanderi. On the boundary of its southern range, larch mixes with evergreen conifers (Siberian pine, Pinus sibirica Du Tour, fir, Abies sibirica Ledeb, spruce, Picea obovata Ledeb., Pinus sylvestris L.), and hardwoods (Populus tremula L., Betula pendula Roth., B. pubescence Ehrh.). Within permafrost areas, larch competes effectively with "dark needle conifers" (Siberian pine, fir and spruce) due to its deciduous nature and dense bark that protects against winter desiccation and snow abrasion (Kharuk et al. 2013). Larch species are also more resistant to wildfires in comparison with "dark needle conifers". Moreover, larch is a pyrophytic species, i.e., wildfires promote seed germination and growth by reducing moss and lichen groundcover. Consequently, age of larch stands regularly corresponds to the dates of intensive (stand replacing) ground fires. Fresh burns are also occupied by Betula pendula and alder (Duschekia fruticosa (Rupr.) Pouzar). Within permafrost areas, larch forms mainly open stands. Closed stands are typically located on well-drained soils along streams and rivers.

Larch dominated communities are known to be a carbon sink (e.g., Schuur et al. 2015). Meanwhile, increasing permafrost temperatures in Siberia (e.g., Romanovsky et al. 2017) are leading to increased carbon (C) release. Vegetation and larch stands, in particular, may influences the rate of $\mathrm{C}$ release by carbon assimilation due to potentially increased primary productivity as a result of longer growing seasons and soil fertilization (Schuur et al. 2008).

Larix dahurica Turcz is a highly ecologically adaptive species with range from about $72^{\circ}+$ north to the southern Siberian and Mongolian forest-steppes $\left(\sim 48^{\circ} \mathrm{N}\right)$. This is a fast growing, drought-resistant, salt-tolerant, shade-intolerant species. Larch is an oligotrophic species and can grow on diverse soil types. Under favorable conditions, larch reaches $35 \mathrm{~m}$ height with diameter up to $1 \mathrm{~m}$. Maximum larch age may exceed 500 years (with up to $\sim 1000$ years reported by Koropachinsky and Vstovskaya 2012). Cones open in the spring spreading seeds over the snow cover; fertile seeds may be retained within cones up to 4 years. L. dahurica can also regenerate by layering (Koropachinsky and Vstovskaya 2012). Larch growth within permafrost areas is limited by poor drainage and a shallow root zone which is compressed within the shallow thawed permafrost layer. This layer regularly is about $30-50 \mathrm{~cm}$ or less within dense moss sites, although on sunny well-drained slopes it may exceeds $1.0 \mathrm{~m}$. Within sites with a dense moss cover larch forms subordinate roots. Larix dahurica, due to a shallow root system, is more vulnerable to surface fires compared to Larix sibirica, which occupies mainly non-permafrost areas and is more resistant to fires by forming thick bark around bole base.

The significant warming observed in the permafrost zone of Siberia suggests an increase in tree growth because temperature is a primary growth-limiting parameter within high latitudes (e.g., Lloyd and Bunn 2007; Richardson and Friedland 2009). Indeed, there are reports on larch stand densification, growth increment increase, and regeneration advance into the tundra (Kharuk et al. 2006; Shiyatov et al. 2007; Esper et al. 2010; Kirdyanov et al. 2013). Larix dahurica growth increase was also reported for the alpine permafrost zone (Zhang et al. 2016). In addition, climate-driven "southern" species (e.g., Pinus sibirica du Tour, Abies sibirica Ledeb) invasion into larch dominated forests was documented by Kharuk et al. (2005). These shade-tolerant species can grow under the larch canopy and consequently with time may replace shade non-tolerant larch in the upper canopy.

Climate-driven growth increase was reported also for some tree species in European and North American forests (e.g., Kullman and Kjällgren 2006; Lenoir et al. 2008; Harsch et al. 2009; McMahon et al. 2010). In addition, the decreasing sensitivity of tree growth indices to temperature during recent decades was reported (D'Arrigo et al. 2005; Andreu-Hayles et al. 2011; Lebourgeois et al. 2012), including European larch (Larix decidua Mill.). 
(Coppola et al. 2012). This effect may be attributed to increased water stress caused by elevated temperatures (Kharuk et al. 2015). Growth increment decrease of Larix sibirica during "warming hiatus" (i.e., from late 1990s until ca. 2013) was documented for semi-arid areas (Liu et al. 2013), whereas within areas of sufficient precipitation (i.e., high elevations) a steady growth increase was observed (Kharuk et al. 2015).

This study aims to analyze Larix dahurica Turcz growth response to warming within a typical permafrost area in Central Siberia. We hypothesize that larch growth response to warming should be sensitive to both, temperature and water regime changes.

\section{Study area}

The study area was located within the Kotuy River watershed in the Putorana Plateau. This area is underlain by permafrost soil and is at the northern larch range in Central Siberia (Fig. 1). Annual precipitation average is $375 \mathrm{~mm}$ (195 mm in June, July and August (JJA)) between 1980 and 2016. Mean July and January temperatures were $+14^{\circ} \mathrm{C}$ and $-34^{\circ} \mathrm{C}$, respectively. Within this area, Larix dahurica forms mainly low-closure stands on cryosols (clay permafrost soils). The mean upper tree line limit is about $500 \mathrm{~m}$ a.s.l. Along with larch, a shrub form of alder (Duschekia fruticose; mean height about $2 \mathrm{~m}$ ) occurs within wind-protected areas. Ground cover is composed of sedge, lichen, and moss. Small shrubs included Betula nana L., Salix sp., and Vaccinium sp. Historically, wildfire activity within the area is low (fire return intervals about 200 years) (Kharuk et al. 2016a).

\section{Materials and methods}

We used field studies, remote sensing (Terra/MODIS and GRACE satellite data) and dendrochronology data for our analysis. Field measurements were taken within the Kotuy River valley within an elevation range of 270-480 $\mathrm{m}$ and with slopes up to $7^{\circ}$ (see Fig. 1). We used small boats to transport personnel and supplies down the Kotuy River between helicopter drop off and pick up points. The total covered distance was $135 \mathrm{~km}$. The area was explored along five transects (mean length $2.6 \mathrm{~km}$ ) positioned across the river valley and covered the variety of larch stands within the study area. In addition, samples were taken from a "hill site" (elevation $450 \mathrm{~m}$ with a southwest facing steep (about $15^{\circ}$ ) slope; Fig. 1). Temporary test sites (TS; Table 1) were located along transects with about $170 \mathrm{~m}$ between them (total number $=55)$. The TS radius $(R=9.8 \mathrm{~m}$ or $15 \mathrm{~m})$ was selected depending on stand closure. Data collected within TS included geolocation, tree height, DBH (diameter at breast height $=1.3 \mathrm{~m}$ ), vigor (for trees with $\mathrm{DBH}>3 \mathrm{~cm}$ ), permafrost and moss and lichen cover depth, shrubs, ground cover and soil description. Permafrost depth was measured with a metal rod. Samples for dendrochronological analysis were taken with an increment borer at DBH height in each TS. 162 trees in total were sampled (about 32 samples per transect).

The reason for the "hill site" (HS) selection was there were visual signs of different trees health status in close proximity. Thus, trees located within channels of ephemeral streams had green healthy needles ("healthy cohort"), whereas needles of trees located between adjacent channels were chlorotic ("declining cohort"). Soils within channels were brown-clay permafrost, whereas between channels soils were rocky with poor water holding capacity. Twenty trees were sampled for both cohorts for comparative growth pattern analysis.

\section{Dendrochronology analysis}

Tree ring widths were measured using LINTAB III device (precision of $0.01 \mathrm{~mm}$ ). Cross-dating was performed by standard methods as described by Rinn (1996). For cross-dating statistical analysis and generalized chronologies construction ARSTAN (v.44), COFECHA, and TSAP software were used. Individual chronologies with low correlation with the master-chronology were deleted from further analysis. The Regional Curve Standardization (RCS) method (ARSTAN v.44) was applied for construction of standard chronologies and elimination of growth 
trends (Esper et al. 2003; Sullivan et al. 2016). As a result, growth indices (GI), that is relative indices of the radial growth, were obtained.

\section{Climate variables and GPP/NPP data}

Larch growth was analyzed with respect to the main climate variables: air temperature, precipitation, drought index, vapor pressure deficit (VPD), and vegetation period length. The latter was defined as a number of days with $t>+10^{\circ} \mathrm{C}$. Although Rossi et al. (2008) showed that cambium of conifers is activated by temperatures within the range of $+4 \ldots+6^{\circ} \mathrm{C}$, we found that using $t>+10^{\circ} \mathrm{C}$ provides the best fit. Soil moisture content was estimated based on monthly GRACE-derived Equivalent of Water Thickness Anomalies (EWTA) data. EWTA accuracy is reported as 10-30 $\mathrm{mm} \mathrm{month}^{-1}$ with spatial resolution $1^{\circ} \times 1^{\circ}$ (Long et al. 2014; http://www.grace.jpl.nasa.gov). Climate variables were obtained from NASA's MERRA2 databases (grid $0.5^{\circ} \times 0.625^{\circ}$; https://disc.sci.gsfc.nasa.gov/datasets), and from the nearest meteorological station (WMO 23383 “Agata”, 66.88 ${ }^{\circ}$, $83.47^{\circ} \mathrm{E}, \sim 250 \mathrm{~km}$ distance from the study site). Drought index SPEI (The Standardized PrecipitationEvapotranspiration Index) is defined as the difference $\left(D_{i}\right)$ between precipitation amount $\left(P_{i}\right)$ and potential evapotranspiration $\left(P E T_{i}\right)$, where $i$ - period, data are normalized in space and time (Vicente-Serrano et al. 2010). SPEI data were obtained from http://sac.csic.es/spei (grid $\left.0.5^{\circ} \times 0.5^{\circ}\right)$. SPEI was considered for the growing season months of June-August within the study area. Gross Primary Productivity (GPP) and Net Primary Productivity (NPP) data were acquired from NASA's Terra/MODIS as 8-day composites products (https://lpdaac.usgs.gov/dataset_discovery/modis/modis products table, see tables mod17a2h and mod17a3h).

\section{Results}

\section{Climate variables dynamic}

Summer temperatures and the number of days with temperatures $t>0{ }^{\circ} \mathrm{C}$ and $t>+5^{\circ} \mathrm{C}$ increased since 1970 (Fig. 2a,f). A minor summer precipitation increase occurred during 1980-1990 along with a strong precipitation variability increase observed since the 1970s (Fig. 2c). The drought index, SPEI, showed a continuous decreasing trend (Fig. 2e) which indicates increasing impact of drought conditions since the 1950s. Seasonal SPEI pattern has also changed significantly since the 1990s, with June becoming the driest month (Fig. 2d). Vapor pressure deficit strongly increased since the year 2000 (Fig. 2e).

\section{Larch growth index (GI) dynamics}

Growth index chronologies were highly correlated $(r=0.82)$ for all five transects. In addition, the growth pattern of the "healthy cohort" within "hill site" was similar to those chronologies. Based on this, "healthy cohort" samples were combined with transect data (total sample size $N=182$ ). Larch GI increase has been observed since the mid1970s followed by GI depression since the late 1990s (Fig. 3). Minimal GI values corresponded to severe droughts (e.g., 1989, 1999, and 2010) and extremely cold years (e.g., 1989). The declining trees cohort responded to warming by general GI depression without any period of GI stimulation by elevated temperature (Fig. 3).

\section{Larch GI vs climate variables and GPP}

Larch growth index (GI) correlated with air temperature, water regime parameters (June precipitation, vapor pressure deficit VPD, drought index, and soil water anomalies of previous year), and growth period length (Fig. 4). Over recent decades (since ca. 1990) larch showed increased sensitivity to atmospheric drought (indicated by VPD and SPEI) (Fig. 4c,f; Fig. 5a,b). That is especially noticeable for declining trees cohort, which showed drought sensitivity even in winter months due to winter desiccation. GI relationship with SPEI changed from negative in 
1980s to positive in the mid-1990s. Soil water stored during the previous year is also significant for larch growth (Fig. 4e). GI of declining trees cohort is sensitive to prior year August precipitation $(r=0.33, p<0.1)$.

Growth increment correlations with air temperatures changed from positive to non-significant for both cohorts and even negative (April-May; Fig. 5c,d). Running correlation showed a positive correlation between GI and air temperature until ca. 1990 with a following decrease in correlation (Fig. 6).

There was a good correlation of larch GI and GPP $\left(r^{2}=0.64\right)$, whereas correlation with NPP is poor $\left(r^{2}=0.19\right.$; Fig. 7a). Notably, within the study area larch GPP showed a strong positive temporal trend, whereas NPP values stagnated (Fig. 7b).

\section{Discussion}

The results show that within the study area air temperatures, since 1970 , have risen $+0.4^{\circ} \mathrm{C}$ per decade in summer $\left(+0.5^{\circ} \mathrm{C}\right.$ mean annual $)$, which is consistent with reported values for high-latitude regions $\left(+0.4^{\circ} \mathrm{C}\right.$ per decade; Hartmann et al. 2013). The general pattern of larch response to that warming was two-phased: GI increased since the onset of warming in the 1970s, which lasts until ca. 1990 with a following growth depression. Period of GI increase correlated with summer air temperature, whereas a depression in growth was caused by increased water stress (vapor pressure deficit and drought increase). The phenomenon of drought impact on the tree growth within permafrost was not observed before the onset of warming. Within Siberia, a similar two-phase pattern of growth response to warming was found for Larix sibirica in semi-arid areas in southern Siberia (Kharuk et al. 2018) and for precipitation-sensitive species (i.e., Pinus sibirica Du Tour, Abies sibirica Ledeb) in more humid southern taiga habitat (Kharuk et al. 2016b, 2017a).

In earlier studies (e.g., Kirdyanov 2010), larch growth in high latitudes and high elevations was considered to be limited by temperature. According to our study, larch growth followed temperature at the beginning of the warming only. Further warming caused growth depression from water stress increase at the beginning of the vegetation period. The seasonal pattern of drought index SPEI changed since the 1990s indicating a strong increase in atmospheric drought in June. According to Novick et al. (2016), atmospheric demand limits evapotranspiration to a greater extent than soil moisture. Changes in SPEI and especially a rapid increase in vapor pressure deficit resulted in a negative impact on growth of both healthy and declining trees (Fig. 4c,d). The limitation of growth due to water stress is also indicated by GI dependence on the amount of soil water acquired during the previous year (Fig. 4e). Indeed, study stands received limited summer precipitation (195 mm received mainly during August) to go along with increasing vapor pressure deficit and drought. Moreover, high inter-annual precipitation variability caused periodic droughts (Fig. 2b,c). The results obtained coincided with Restaino et al. (2016) observation of forests in the western US, where increased temperature suppressed Douglas fir (Pseudotsuga menziesii (Mirb.) Franco) growth via increased vapor pressure deficit. The divergence between tree growth and elevated temperature were also discussed for Alaskan forests (Andreu-Hayles et al. 2011). The negative effect of warming was also described for Larix sibirica Ledeb and Pinus silvestris L. growth in semi-arid forests of Interior Asia (Liu et al. 2013).

The sensitivity of Larix dahurica growth index to temperature decreased since ca. 1990, whereas sensitivity to drought increased (Fig. 5,6). The loss of the temperature signal in the tree-ring chronologies was also described for European larch (Larix decidua Mill.) (Coppola et al. 2012). Franceschini et al. (2013) also pointed that tree-ring indices tracked the rising temperature up to a certain point and then began decreasing as temperatures continued rising. A change of primary growth factor from temperature to available water was also described for Pinus mugo Turra at higher elevations in the Alps Mountains (Churakova et al. 2016).

In our study area, the switch from growth limitation by temperature to limitation by water was primarily observed in the declining trees cohort located on soils with low water-holding capacity (Fig. 5a). In addition, 
elevated spring (April-May) temperatures had a negative impact on the growth of both cohorts (Fig. 5c,d). This may be related to cambium activation caused by early spring warming followed by frost damage.

Further increase of drought frequency (as predicted by e.g., Pachauri et al. 2014) may lead to larch decline and mortality in drought-prone areas (as, for example, within declining trees habitat with south facings slopes with soils of low water holding capacity). This effect has also been reported for "dark needle" conifers (Pinus sibirica, Abies sibirica) in southern Siberia (Kharuk et al. 2016b). At the same time water deficit may be partially mitigated by an increased permafrost thaw depth that encourages tree growth (Sugimoto et al. 2002; Romanovsky et al. 2017). According to Zhang et al. (2016) that effect was observed for high elevation Larix dahurica stands in Northern China, where synergy of permafrost thawing and air temperature increase stimulated larch growth.

Meanwhile larch communities GPP within permafrost areas showed a strong positive trend in the 2000s on the background of NPP stagnation (Fig. 7); the latter should be attributed to increased respiration demands caused by elevated temperatures and atmospheric drought. NPP stagnation was approximated by larch GI decrease in the $21^{\text {st }}$ century, which is understandable because GI is the NPP proxy. In spite of larch GI decrease since the late 1990 s, mean decadal larch GI values were higher in the $21^{\text {st }}$ century than in the pre-warming (1950-1970) period ( $0.84 \pm 0.03$ and $1.24 \pm 0.06$, respectively).

Permafrost degradation simulations predicts higher carbon fluxes as the effects of increasing temperatures. (Schuur et al. 2015) However, decomposition occurring within thawing permafrost can lead to increased soil fertilization that can intensify plant growth and mitigate carbon losses (Koven et al. 2015). Wildfires in permafrost forests result in thawing of permafrost and an increase in the active layer. This impact may serve as a proxy (in the sense of thaw depth) of the impact of warming on permafrost. Thus, after wildfires, seasonal permafrost thaw depth may increase up to 3-4 times with a 2-3 times GI increase (up to 7-8 on the drained soils; Kharuk et al. 2011). Fire frequency itself within the study area was rather low before warming (with fire return intervals about 200 years, Kharuk et al. 2016a). Meanwhile warming-induced fire frequency and burned area increase are being observed (and predicted) in the larch taiga (Kharuk and Ponomarev 2017b). Increased wildfire rate should be favorable for larch since this promotes regeneration eliminates competitive species (e.g., Siberian pine and fir). However, there are still uncertainties. For example, warming increases larch competition with less cold-tolerant invaders such as Pinus sibirica, Abies sibirica, Picea obovata, and Pinus sylvestris. The harsh environment favors frost-resistant larch species and its domination within the permafrost zone. Thus, one of the expected consequences of warming and permafrost thawing is decreasing the proportion of larch within the northern Siberian taiga (Kharuk et al. 2005).

\section{Conclusions}

1. Within the permafrost zone in northern Siberia climate warming caused a two-phase impact on larch trees: growth increase from 1970s until ca. 1990 followed by a growth depression.

2. Growth increase correlated with summer temperature, whereas growth depression was caused by increased water stress (vapor pressure deficit and drought increase). This phenomenon was not observed before onset of warming.

3. Larch growth sensitivity to temperature decreased since ca. 1990 and increased for precipitation.

4. GPP of larch communities increased since 2000s, whereas NPP values stagnated.

Acknowledgements Authors thank P. Montesano and C.S.R. Neigh for help with field measurements.

Funding: This study were funded by Russian fund of fundamental investigations RFFI 18-05-00432\18 and NASA's Terrestrial Ecology program supported Kutoy River field measurements.

Conflict of Interest: The authors declare that they have no conflict of interest. 


\section{References}

Andreu-Hayles L, D’Arrigo R, Anchukaitis KJ, Beck PS, Frank D, Goetz S (2011) Varying boreal forest response to Arctic environmental change at the Firth River, Alaska. Environ Res Lett 6:041004. doi:10.1088/17489326/6/4/049502

Bartalev SA, Egorov VA, Ershov DV, Isaev AS, Loupian EA, Plotnikov DE, Uvarov IA (2011) The vegetation mapping over Russia using MODIS spectroradiometer satellite data. Contemporary Earth Remote Sensing from Space 8:285-302 (in Russian)

Churakova SO, Saurer M, Bryukhanova MV, Siegwolf RT, Bigler C (2016) Site-specific water-use strategies of mountain pine and larch to cope with recent climate change. Tree Physiol 36:942-953. doi:10.1093/treephys/tpw060

Coppola A, Leonelli G, Salvatore MC, Pelfini M, Baroni C (2012) Weakening climatic signal since mid-20th century in European larch tree-ring chronologies at different altitudes from the Adamello-Presanella Massif (Italian Alps). Quat Res 77(3):344-354. doi:10.1016/j.yqres.2012.01.004

D’Arrigo R, Mashig E, Frank D, Wilson R, Jacoby G (2005) Temperature variability over the past millennium inferred from Northwestern Alaska tree rings. Clim Dyn 24:227-236. doi:10.1007/s00382-004-0502-1

Esper J, Cook ER, Krusic PJ, Peters K, Schweingruber FH (2003) Tests of the RCS method for preserving lowfrequency variability in long tree-ring chronologies. Tree-Ring Res 59(2):81-98.

Esper J, Frank DC, Büntgen U, Verstege A, Hantemirov RM, Kirdyanov AV (2010) Trends and uncertainties in Siberian indicators of 20th century warming. Global Change Biol 16:386-398. doi:10.1111/j.13652486.2009.01913.x

Franceschini T, Bontemps J, Perez V, Leban J (2013) Divergence in latewood density response of Norway spruce to temperature is not resolved by enlarged sets of climatic predictors and their non-linearities. Agric Forest Meteorol 180:132-141.

Harsch M, Hulme P, McGlone M, Duncan R (2009) Are treelines advancing? A global meta-analysis of treeline response to climate warming. Ecol Lett 12:1040-1049. doi:10.1111/j.1461-0248.2009.01355.x

Hartmann DL, Klein Tank AMG, Rusticucci M, Alexander LV, Brönnimann S, Charabi Y, Dentener FJ, Dlugokencky EJ, Easterling DR, Kaplan A, Soden BJ, Thorne PW, Wild M, Zhai PM (2013) Observations: Atmosphere and Surface. In: Stocker TF, Qin D, Plattner G-K, Tignor M, Allen SK, Boschung J, Nauels A, Xia Y, Bex V, Midgley PM (eds) Climate Change 2013: The Physical Science Basis. Contribution of Working Group I to the Fifth Assessment Report of the Intergovernmental Panel on Climate Change. Cambridge University Press, Cambridge, United Kingdom and New York, NY, USA, pp 159-254. http://www.ipcc.ch/pdf/assessment-report/ar5/wg1/WG1AR5_Chapter02_FINAL.pdf. Accessed 25 July 2018

Kharuk VI, Dvinskaya ML, Ranson KJ, Im ST (2005) Expansion of evergreen conifers to the larch-dominated zone and climatic trends. Rus J Ecol 36:164-170. doi:10.1007/s11184-005-0055-5

Kharuk VI, Ranson KJ, Im ST, Dvinskaya ML (2006) Forest-tundra larch forests and climatic trends. Rus J Ecol 37(5):291-298. doi:10.1134/S1067413606050018

Kharuk VI, Ranson KJ, Dvinskaya ML, Im ST (2011) Wildfires in northern Siberian larch dominated communities. Environ Res Lett 6:045208. doi:10.1088/1748-9326/6/4/045208

Kharuk VI, Ranson KJ, Im ST, Oskorbin PA, Ovchinnikov DV (2013) Tree Line Structure and Dynamics at the Northern Limit of the Larch Forest: Anabar Plateau, Siberia, Russia. Arct Antarct Alp Res 45:526-537. doi:10.1657/1938-4246-45.4.526 
Kharuk VI, Ranson KJ, Im ST, Petrov IA (2015) Climate-induced larch growth response within Central Siberian permafrost zone. Environ Res Lett 10:125009. doi:10.1088/1748-9326/10/12/125009

Kharuk VI, Dvinskaya ML, Petrov IA, Im ST, Ranson KJ (2016a) Larch Forests of Middle Siberia: Long-Term Trends in Fire Return Intervals. Reg Environ Change 16:2389-2397. doi 10.1007/s10113-016-0964-9

Kharuk VI, Im ST, Petrov IA, Golyukov AS, Ranson KJ, Yagunov MN (2016b) Climate-induced mortality of Siberian pine and fir in the Lake Baikal Watershed, Siberia. For Ecol Manage 384:191-199. doi:10.1016/j.foreco.2016.10.050

Kharuk VI, Im ST, Petrov IA, Dvinskaya ML, Fedotova EV, Ranson KJ (2017a) Fir Decline and Mortality in the Southern Siberian Mountains. Reg Environ Change 17(3):803-812. doi:10.1007/s10113-016-1073-5

Kharuk VI, Ponomarev EI (2017b) Spatiotemporal characteristics of wildfire frequency and relative area burned in larch-dominated forests of Central Siberia. Russian J Ecol 48 (6):507-512. doi:10.1134/S1067413617060042

Kharuk VI, Petrov IA, Dvinskaya ML, Im ST, Sushpanov AS (2018) Comparative reaction of larch (Larix sibirica Ledeb) radial increment to climate change in the forest-steppe and highlands of Southern Siberia. Contemp Probl Ecol 11(4):388-395. doi:10.15372/sej20180405 (in Russian)

Kirdyanov AV, Prokushkin AS, Tabakova MA (2013) Tree-ring growth of Gmelin larch under contrasting local conditions in the north of Central Siberia. Dendrochronologia 31:114-119. doi:10.1016/j.dendro.2012.10.003

Koven CD, Lawrence DM, Riley WJ (2015) Permafrost carbon-climate feedback is sensitive to deep soil carbon decomposability but not deep soil nitrogen dynamics. Proc Natl Acad Sci USA 112:3752-3757

Koropachinsky IYu, Vstovskaya TN (2012) Tree species of Russian Asia, 2nd edn. Geo, Novosibirsk, Russia (in Russian)

Kullman L, Kjallgren L (2006) Holocene pine tree-line evolution in the Swedish Scandes: recent tree-line rise and climate change in a long-term perspective. Boreas 35:159-168. doi:10.1111/j.1502-3885.2006.tb01119.x

Lenoir J, Gegout JC, Marquet PA, de Ruffray P, Brisse H (2008) A significant upward shift in plant species optimum elevation during the 20th century. Science 320(5884):1768-1771. doi:10.1126/science.1156831

Lebourgeois F, Merian P, Courdier F, Ladier J, Dreyfus P (2012) Instability of climate signal in tree-ring width in Mediterranean mountains: a multi-species analysis. Trees 26:715-729. doi: 10.1007/s00468-011-0638-7

Lloyd AH, Bunn AG (2007) Responses of the circumpolar boreal forest to 20th century climate variability. Environ Res Lett 2:045013. doi:10.1088/1748-9326/2/4/045013

Long D, Longuevergne L, Scanlon BR (2014) Uncertainty in evapotranspiration from land surface modeling, remote sensing, and GRACE satellites. Water Resour Res 50:1131-1151. doi:10.1002/2013WR014581

Liu H, Williams AP, Allen CD, Guo D, Wu X, Anenkhonov OA, Liang E, Sandanov DV, Yin Y, Qi Z, Badmaeva NK (2013) Rapid warming accelerates tree growth decline in semi-arid forests of Inner Asia. Global Change Biol 19:2500-2510. doi:10.1111/gcb.12217

McMahon SM, Parker GG, Miller DR (2010) Evidence for a recent increase in forest growth. Proc Natl Acad Sci 107:3611-3615. doi:10.1073/pnas.0912376107

Novick KA, Ficklin DL, Stoy PC, Williams CA, Bohrer G, Oishi AC, Papuga SA, Blanken PD, Noormets A, Sulman BN, Scott RL, Wang L, Phillips RP (2016) The increasing importance of atmospheric demand for ecosystem water and carbon fluxes. Nat Clim Chang 6:1023-1027. doi: 10.1038/nclimate3114

Pachauri RK, Allen MR, Barros VR, Broome J, Cramer W, Christ R, Church JA, Clarke L, Dahe Q, Dasgupta P, Dubash NK, Edenhofer O, Elgizouli I, Field CB, Forster P, Friedlingstein P, Fuglestvedt J, GomezEcheverri L, Hallegatte S, Hegerl G, Howden M, Jiang K, Jimenez Cisneroz B, Kattsov V, Lee H, Mach KJ, Marotzke J, Mastrandrea MD, Meyer L, Minx J, Mulugetta Y, O'Brien K, Oppenheimer M, Pereira JJ, 
Pichs-Madruga R, Plattner GK, Pörtner HO, Power SB, Preston B, Ravindranath NH, Reisinger A, Riahi K, Rusticucci M, Scholes R, Seyboth K, Sokona Y, Stavins R, Stocker TF, Tschakert P, van Vuuren D, van Ypserle JP (2014) Climate change 2014: synthesis report. Contribution of working groups I, II and III to the fifth assessment report of the intergovernmental panel on climate change. IPCC, Geneva, Switzerland. http://epic.awi.de/37530/1/IPCC_AR5_SYR_Final.pdf. Accessed 23 April 2018

Restaino CM, , Peterson DL, Littell J (2016) Increased water deficit decreases Douglas fir growth throughout western US forests. Proc Natl Acad Sci 113: 9557-9562. doi:10.1073/pnas.1602384113

Richardson AD, Friedland AJ (2009) A review of the theories to explain Arctic and alpine treelines around the world. J Sustainable For 28:218-242. doi:10.1080/10549810802626456

Rinn F (1996) Tsap V 3.6. Reference manual: computer program for tree-ring analysis and presentation. Heidelberg, Germany

Romanovsky VE, Smith SL, Shiklomanov NI, Streletskiy DA, Isaksen K, Kholodov AL, Christiansen HH, Drozdov DS, Malkova GV, Marchenko SS (2017) Terrestrial Permafrost [in "State of the Climate in 2016"]. Bull Am Meteorol Soc 98(8):147-149. doi:10.1175/2017BAMSStateoftheClimate.1

Rossi S, Deslauriers A, Griçar J, Seo J-W, Rathgeber CBK, Anfodillo T, Morin H, Levanic T, Oven P, Jalkanen R (2008) Critical temperatures for xylogenesis in conifers of cold climates. Glob Ecol Biogeogr 17:696-707. doi:10.1111/j.1466-8238.2008.00417.x

Shiyatov SG, Terent'ev MM, Fomin VV, Zimmermann NE (2007) Altitudinal and horizontal shifts of the upper boundaries of open and closed forests in the Polar Urals in the 20th century. Russian J Ecol 38:223-227. doi:10.1134/S1067413607040017

Schuur EAG, Bockheim J, Canadell JG, Euskirchen E, Field CB, Goryachkin SV, Hagemann S, Kuhry P, Lafleur PM, Mazhitova HLG, Nelson FE, Rinke A, Romanovsky VE, Shiklomanov N, Tarnocai C, Venevsky S, Vogel JG, Zimov SA (2008), Vulnerability of permafrost carbon to climate change: Implications for the global carbon cycle. BioScience 58(8):701-714. doi:10.1641/B580807

Schuur EAG, McGuire AD, Schädel C, Grosse G, Harden JW, Hayes DJ, Hugelius G, Koven CD, Kuhry P, Lawrence DM, Natali SM, Olefeldt D, Romanovsky VE, Schaefer K, Turetsky MR, Treat CC, Vonk JE (2015) Climate change and the permafrost carbon feedback. Nature 520:171-179. doi:10.1038/nature14338

Sugimoto A, Yanagisawa N, Naito D, Fujita N, Maximov TC (2002) Importance of permafrost as a source of water for plants in east Siberian taiga. Ecol Res 17:493-503. doi:10.1046/j.1440-1703.2002.00506.x

Sullivan PF, Pattison RR, Brownlee AH, Cahoon SM, Hollingsworth TN (2016) Effect of tree-ring detrending method on apparent growth trends of black and white spruce in interior Alaska. Environ Res Lett 11:114007. doi:10.1088/1748-9326/11/11/114007

Vaganov EA, Kirdyanov AV (2010) Denrochronology of larch trees growing on Siberian permafrost. In Osawa A, Zyryanova OA, Matsuura Y, Kajimoto T, Wein RW (eds) Permafrost Ecosystems: Siberian Larch Forests. Ecological Studies 209. Heidelberg, Berlin, Springer-Verlag, NewYork, pp 347-363. doi:10.1007/978-14020-9693-8_18

Vicente-Serrano SM, Beguería S, López-Moreno JI (2010) A multiscalar drought index sensitive to global warming: the standardized precipitation evapotranspiration index. J Clim 23:1696-718. doi:10.1175/2009JCLI2909.1

Zhang X, Ba X, Chang Y, Chen Z (2016) Increased sensitivity of Dahurian larch radial growth to summer temperature with the rapid warming in Northeast China. Trees 30:1799-1806. doi:10.1007/s00468-016$1413-6$ 